Relations industrielles

Industrial Relations

\title{
Gospel, Howard F., Markets, Firms and the Management of \\ Labour in Modern Britain
}

\section{Terry Hercus}

Volume 48, numéro 2, 1993

URI : https://id.erudit.org/iderudit/050862ar

DOI : https://doi.org/10.7202/050862ar

Aller au sommaire du numéro

Éditeur(s)

Département des relations industrielles de l'Université Laval

ISSN

0034-379X (imprimé)

1703-8138 (numérique)

Découvrir la revue

Citer ce compte rendu

Hercus, T. (1993). Compte rendu de [Gospel, Howard F., Markets, Firms and the Management of Labour in Modern Britain]. Relations industrielles / Industrial Relations, 48(2), 366-369. https://doi.org/10.7202/050862ar

Tous droits réservés @ C Département des relations industrielles de l'Universite Laval, 1993
Ce document est protégé par la loi sur le droit d'auteur. L’utilisation des services d'Érudit (y compris la reproduction) est assujettie à sa politique d'utilisation que vous pouvez consulter en ligne.

https://apropos.erudit.org/fr/usagers/politique-dutilisation/ 
own dispute-resolution procedures, (2) government or state involvement in the selection of a special dispute resolution procedure for industries or occupations in which workers are not sufficiently well organized to establish procedures themselves; in addition, the procedures will apply to all aspects of the employment relationship; (3) resolution of the dispute must be either strike or arbitration and parties wishing to use the strike approach must obtain permission from an independent commission; (4) penalties against parties defying a no-strike or lockout provision; and (5) retaining conciliation services.

The book is well written and the arguments of the authors are presented in a logical manner. In addition, the authors support their position with considerable reference to the empirical and theoretical literature from Canada, the United States, Britain and Australia. Individuals unfamiliar with the literature on arbitration could develop a good bibliography merely by referencing the notes provided at the end of the book.

While scholars of interest arbitration will probably find that the book covers a lot of familiar ground, the authors achieve their objective of contributing to the review of the forms of collective bargaining. Although the book contains insights worthy of consideration by practitioners, it will probably be of more interest to academics. The authors could provide more discussion and analysis of some of the drawbacks associated with interest arbitration as well as elaborate on potential union resistance to their proposals. Nevertheless, the authors don't simply hide behind the cloak of recommending interest arbitration; rather, they outline the elements which should be contained in legislation. Despite the rather extensive literature on interest arbitration and strikes, a careful reading of this book raises several important questions and underscores the need for more research on dispute resolution.

Terry H. WAGAR

Saint Mary's University

Markets, Firms and the Management of Labour in Modern Britain, by Howard F. Gospel, Cambridge, UK, Cambridge University Press, 1992, 256 p., ISBN 0-521-41527-6

This book examines the development of labour management in Britain from the late nineteenth century up to the present time. It deals with employers' human resource and industrial relations policies in a broad historical perspective, focusing on how managers organize the employment relationship, how they control work relations and how they deal with trade unions and industrial relations. These three major topics are examined in three historical periods: late nineteenth century, twentieth century up to the second world war and post-war years. They are analyzed in the context of the product and labour markets within which the firm operates, and the strategy, structure, and hierarchy of the modern industrial enterprise.

The purpose of the book is to explore five propositions that influence labour management decisions. Markets for both labour and final products are key independent variables influencing labour management decisions. Corporate strategies and structures are significant intervening variables shaping strategy and structure in the labour field. The 
nature and quality of the managerial hierarchy is a further important factor influencing labour management. Technology and the division of labour also shape labour decisions. Firms make labour decisions which can be conceptualized in terms of internalising transactions within the firm or externalising them in the market.

The British economy in the late nineteenth and early twentieth centuries was characterized by a large number of small, family-owned and managed enterprises catering for highly differentiated markets at home and abroad. Managerial hierarchies were weak and owner often relied on various forms of sub-contracting and on largely independent foremen for workplace control. For the most part employers pursued a laissez-faire approach to the employment relationship; confronted by a buyer's market for labour, they accepted little responsibility for employment security and welfare benefits.

In the late Victorian period there was increased recognition by employers of trade unions for male manual workers. Employers took the initiative in developing a system of regional collective bargaining based on membership of employers' organizations. World War I conditions brought about a significant growth of collective bargaining: shopfloor bargaining grew in importance and, to contain it, employers sought to extend formal bargaining through employers' associations at the industry level. Most large firms continued to be managed by family members and remained loosely coordinated with weak managerial structures.

In the interwar years, high unemployment provided little incentive to innovation in terms of employment and training. There was a significant extension of industry-wide, multi-employer bargaining. In this way, employers hoped to avoid workplace bargaining, to defend managerial prerogatives and take wages out of competition. In the second world war, further recognition was accorded to trade unions, especially at workplace level, and there was simultaneously an extension of formal industry-wide bargaining arrangements.

Post-war years were marked by accelerated technical innovation, changes in work organization and a growing recognition of the need to build better corporate structures and improved managerial hierarchies. Weaknesses in terms of managerial structures and hierarchies persisted in 1970s and 1980s, however, constraining the development of strategies in the labour management area.

Poor productivity performance from the 1960 s onwards was blamed on restrictive work practices imposed by trade union members in a tight labour market. It became more and more apparent that the formal industry-wide system of collective bargaining was unable to contain the increase in workplace bargaining pressure - growing restrictive practices, unconstitutional strikes, and wage settlements in excess of productivity growth.

From the mid-1960s employers started to take initiative in reforming collective bargaining, moving to single employer bargaining, reform of the wage system and more sophisticated personnel management. Viewed in longer term perspective, these constituted a significant transformation of the British system of collective bargaining.

In the Thatcher government period, trade union membership declined and there were major offensives against traditional union control over working practices in many sectors of the economy. There was a further decentralisation of bargaining structures to 
the plant level and the negotiation of more flexible methods of working. Employers continued to develop internal wage and benefit systems tailored to their own domestic requirements. It is too early to consider these changes as a new system of human resource management in Britain.

Returning to the major themes of the book, it is clear that in terms of labour markets, the excess supply of labour in Britain for much of the period studied, slowed down the growth of internal labour market arrangements and discouraged the development of managerial and technical improvements. The post-Second World War years saw changes in the division of labour and led employers to develop more extensive employment provisons and internal labour markets.

The author finds abundant evidence that corporate structures in Britain remain weak and management is still less well educate and trained than its foreign counterparts, contributing to poor productivity performance in industry. From the 1930s onwards, there was a growth of more bureaucratic internal employment systems, impersonal rules and formal wage and benefit systems. There was some increase in internal training but overall internal labour market arrangements are still relatively weaker in Britain than in U.S.A., Germany or Japan.

In the 1980s training remains a considerable shortcoming, however more attention has been given by management to selection, appraisal and the use of internal transfers and promotions. The trend towards single-employer bargaining has continued with an increased dependence of workplace trade unionism on the employer for its operation. There has been a growth in other kinds of consultative arrangements and forms of employee involvement.

Much of the history of labour management over the post-war years appears to be a hesitant and uncertain attempt to change direction and develop stronger strategies of internalisation. The thesis of the book is that the action and inaction on the management side has been more important than that of trade unions to the poor productivity performance of British industry. It must be stated that unions at various times and in various sectors have had an adverse effect on productivity growth, however, management actions and inactions have played a large part in influencing the productive performance of British industry.

The book has tended to stress the benefits of internalisation which the author believes outweigh the costs. The role of the state has been less important than that of employers as seen in the long-term perspective. It has been argued in the book that large American firms have internalised more activities than their British counterparts. Japanese firms have developed a sophisticated mix of internal policies based on elaborate pay systems, extensive welfare benefits and enterprise trade unionism. This system is also supported by the external use of temporary workers and subcontracting. In Germany, large firms have also developed extensive internal employment sytems, with strong internal labour markets and arrangements for employee representation. It is also complemented by external multi-employer arrangements for training and collective bargaining. While much has been done in terms of improved organization of work relations, in employment conditions and training at all levels and in terms of more positive industrial relations, much remains to be done to strengthen British industry. 
The author's treatment of the management of labour within the environmental context of the industrial enterprise operating within its product and labour market, using its specific technology in its production processes provides the reader with an analysis of an industrial relations system as defined by John Dunlop in his classic text. While the author does not deal with the distribution of power in the larger society, he does provide a fairly comprehensive treatment of Industrial Relations as a system operating within the other two environmental contexts.

Taking his analysis beyond the Dunlop model, the author broadens his definition of industrial relations to cover: Work Relations, Employment Relations, and Industrial Relations. This approach provides the reader with an historical perspective on what has been defined by Michael Beer and his associates from the Harvard Busines School as Human Resource Management. The four major HMR policy areas include: Employee Influence (lndustrial Relations), Human Resource Flow, Reward Systems (Employment Relations), and Work Systems (Work Relations) as defined by the Harvard group. The author also maintains a strong linkage between these HRM activities and the economic performance of the firm, based on the concepts of externalization or internalization of these activities.

The purpose of this book is to examine Labour Management from an historical perspective dealing with it in the larger context of the management of the firm and its markets. This approach to the subject requires extensive historical analysis and an examination of corporate histories as well. The book is extremely well organized and presented, providing a detailed historical narrative on the three major topics of investigation. Propositions are set out in the first chapters, analyzed through the narrative and then answered in the concluding chapter. The chapters are well researched, providing a comprehensive account of the topic for the historic period under discussion. Theses are carried through the text providing a long-term historical perspective on them. Each topic is placed within its social, economic and political context.

The author's purpose has been successfully achieved. The value of the book is that it places Labour Management in the broad context of business history and identifies its contribution to the performance of British industry. It provides a well balanced argument, dealing with a complex set of variables over an extended historical period.

The book is a scholarly text, well suited for students of: Management, Industrial Relations, Human Resource Management, Labour Studies and History.

Terry Hercus

University of Manitoba

Le traité du recours à l'encontre d'un congédiement sans cause juste et suffisante, par Pierre LAPORTE, Montréal, Edition Wilson \& Lafleur, 1992, 576 p., ISBN 2-89127-203-X

Cette nouvelle édition du traité s'inscrit dans ce qui, de toute évidence, constitue un point d'intérêt majeur pour le professeur Pierre Laporte; il indique que cet intérêt tient au fait que ce recours « marque une rupture avec la philosophie établie en matière 